\title{
Eric Hobsbawm: un genio atrapado en la historia'
}

\author{
Eric Hobsbawm: a Genius Trapped in History
}

\author{
FERNANDO ALCALDE RODRÍGUEZ \\ España \\ fernando_alcalde@hotmail.com
}

(Recibido I2-I2-2OI4;

aceptado I6-I2-20I4)

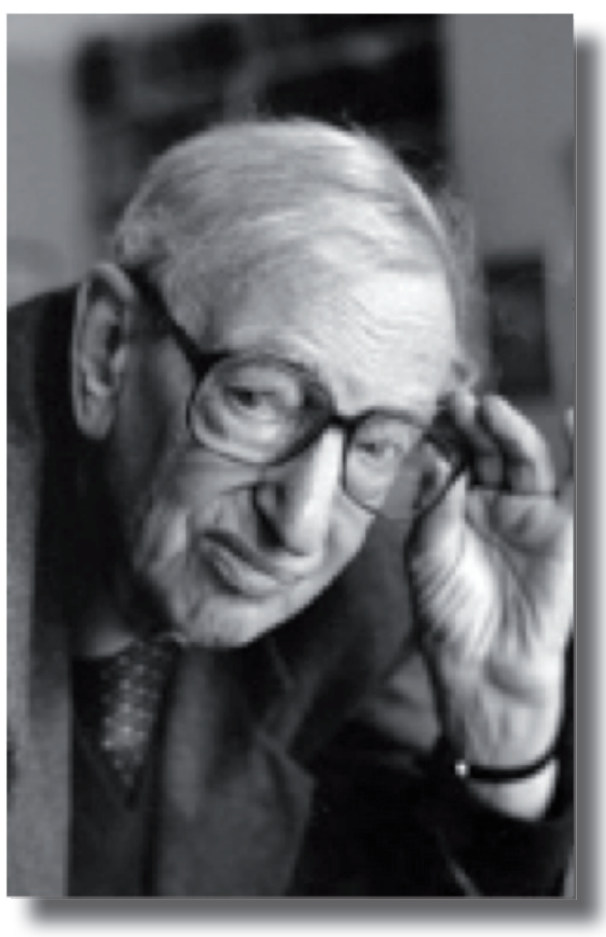

Terry Eagleton llama "Indomable" a este marxista intempestivo que ha admirado a pensadores de la talla de Juan Carlos Rodríguez. Fernando Alcalde llegó a Hobsbawm por casualidad, pero como ocurre con el amor o la amistad, cuando encuentras un pensador de la talla de Eric Hobsbawm sientes una mezcla de sorpresa por no haber reparado en él antes, y de gratitud por tener un autor al que poder serle fiel. Álabe quiere rendir homenaje a un historiador que con su lectura de la historia nos ofrece, como afirma Josep Fontana, "Ia memoria de un siglo". Porque el rigor exquisito de su producción historiográfica no está desprovisto de una narración de la vida material, tantas veces olvidada en el relato de nuestra Historia. Asomarse a la obra de Hobsbawm a través de la mirada de Alcalde, es reconocer junto al autor imprescindible, la veta humana de una escritura comprometida con el presente, indomablemente veraz.

\footnotetext{
${ }^{\text {I }}$ Para citar este artículo: Alcalde Rodríguez, Fernando (2OI4). Eric Hobsbawm: Un genio atrapado en la historia. Alabe 10 [www.revistaalabe.com]

DOI IO.I5645/Alabe.20I4.IO.II
} 
Me sigue causando sonrojo admitir que descubrí Historia del Siglo XX en las páginas de un diario cuya dignidad comenzaba a declinar. Y, aunque se trataba de un encuentro ineludible por razón de afinidades de materia y pensamiento, lo cierto es que estas debieran haberme llevado hasta Eric Hobsbawm mucho antes y por caminos menos fútiles e inmerecidos para el autor.

La crónica que en aquel diario se realizaba reunía todos los ingredientes para constituir el reto veraniego de un lector aficionado a la historia, cuyo atrevimiento solo era superado por la ociosidad. Y así cumplimenté el pedido del albarán electrónico.

Mientras se consumaba la entrega y abusando del mucho tiempo y la facilidad del Internet, descubrí una biografía novelesca propia de la Guerra Fría que, al compartirla con los amigos, se destapó como desconocida tan solo para mí: nació en Alejandría en el año de la revolución rusa, hijo de un mercader británico y una escritora austriaca, ambos judíos, que vivieron a caballo entre Viena y Berlín hasta sus muertes durante la Gran Depresión. Por esta razón, fue adoptado y trasladado a Inglaterra por sus tíos a la edad de I4 años, donde llegó a ser, pese al gobierno británico, “el mayor historiador en lengua inglesa del siglo XX”, en tipografía de la BBC. Aún así, debió esperar hasta la década de los 80 para que Inglaterra pudiera admitir en su Academia a un marxista confeso, miembro del partido comunista británico, reconocido como uno de los genios historiográficos del siglo XX, precursor de la historiografía social y autor de una obra traducida a cuarenta idiomas.

Llegó el libro; un achaparrado volumen rústico de pastas coloridas, letra hormigueante e interlineado intimidatorio, cuyas aglomeradas páginas daban cobertura escenográfica a una lectura tupida en la que el punto de cada párrafo era un asidero para la recapitulación y la oxigenación. Una lectura que es una suma infinita pero sintetizada de fechas, sucesos, cifras y personajes, cada una de ellas imprescindible para sustentar el andamiaje que el historiador va ensamblando con la precisión y el cuidado de quien pretende, ni más ni menos, desplegar, finalmente, una teoría de la historia nueva, creíble y extensa; capaz de generar un entendimiento inédito sobre la construcción del mundo actual. Se trata de una superación de las anécdotas y los personajes, de la explicación teleológica hasta ese momento en manos de actores imprescindibles. Un nuevo universo se abre en su lectura donde los acontecimientos cobran sentido social y económico y donde el lector descubre una realidad universal interpretable desde el espacio y el tiempo en que ocurren, cuyas claves no son ya los personajes sino la sociedad. Y así, sumando párrafos y sedimentando líneas, Eric Hobsbawm (ya saben aquello de la w intrusa por error del registro de nacimiento) desplegó una constelación comprensible.

En mi caso, la lectura de Historia del Siglo $X X$ avanzaba con el convencimiento de que aquella mente lúcida había sido capaz de engranar de forma genial todas aquellas suposiciones que de forma atrevida muchos de nosotros intuíamos más como una sospecha ideologizada que como una construcción coherente. Datos, datos y datos; suma de nuevas apreciaciones e interpretaciones y, finalmente, la ruptura y el alumbramiento de un nuevo paradigma interpretativo. Aquí no son ya los héroes quienes construyen la 
historia sino la siempre presente lucha de los de abajo frente a los de arriba. La quiebra es total hasta en los convencionalismos: para Hobsbawm el Siglo XX empezó con el final de la Primera Guerra Mundial, en I9I7, y terminó con la caída del Muro de Berlín, en I989.

Envalentonado tras la lectura de Historia del Siglo XX, acometí Naciones y nacionalismos desde 178o, una pieza separada de la primera que indaga en una de las cuestiones centrales de la historia europea y también de la discusión de la izquierda: la nación no es una entidad social primaria sino una construcción posterior ligada a un período concreto y reciente, el "Estado Nación”, fruto de la confluencia histórica de procesos políticos, tecnológicos y de transformación social. Una construcción de la burguesía ahora en declive, superada por la expansión del capitalismo que la hace disfuncional, y que tiene en el auge de los mininacionalismos la expresión de su inoperancia. La historia ya no cabe dentro de los límites de los estados-nación, y este ya no es un término adecuado para interpretarla. Hobsbawm dixit.

Y todo este proceso de cambio, ruptura y decadencia tiene su traslación a la manifestación más elegante del poder: el arte. En Un tiempo de rupturas. Sociedad y cultura en el siglo $X X$, Hobsbawm disecciona el gran arte europeo y caracteriza el modelado del canon fundamental de los clásicos como construcciones decimonónicas de la burguesía. Un arte que se expande con ella abarcando a la mayor parte del planeta hasta desaparecer en I9I4. El gran arte europeo languidece como manifestación de la descomposición de la sociedad burguesa tradicional que lo originó y, con ella, los valores que la mantuvieron unida y que fueron proyectados por ese arte, imposible de contener el impacto del desarrollo vertiginoso de la tecnología y la ciencia y su poder para establecer nuevos cánones y valores.

Hobsbawm, perteneciente a "la generación para quienes la revolución bolchevique representó una esperanza para el mundo”, apadrinó a una nueva escuela de historiadores y politólogos que construyeron una nueva visión de la historia, pues consideraba que "nos enfrentamos a los problemas del siglo XXI con un conjunto de mecanismos políticos radicalmente inadecuados para abordarlos". Entre ellos se encontraba Ernesto Laclau, al que encajo al final de esta admiración en forma de escrito por su relevante actualidad ante los fenómenos políticos de nuevo cuño que están reescribiendo la comprensión de la sociedad postindustrial del siglo XXI en América Latina y, al parecer, también en España.

Eric Hobsbawm murió en la mañana de un lunes en el Royal Free Hospital de Londres a los 95 años, después de una larga enfermedad. "La injusticia social necesita ser denunciada y combatida... ya que el mundo no se va a arreglar por sí solo”, dejó dicho. Su determinación reside en el convencimiento de que la humanidad se enfrenta al reto de un nuevo mundo sin resolver las causas que dieron lugar a las dos grandes guerras, y que no son otras distintas que la enorme desigualdad entre los seres humanos. 